\title{
PERISTIWA KOMUNIKASI DALAM PEMBENTUKAN KONSEP DIRI OTAKU ANIME
}

\author{
Uliviana Restu Handaningtias ${ }^{1}$ dan Helmy Agustina $^{2}$ \\ ${ }^{1,2}$ Universitas Sultan Ageng Tirtayasa
}

\begin{abstract}
ABSTRAK
Otaku anime adalah istilah untuk menyebutkan seseorang yang memiliki obsesi terhadap film animasi yang berasal dari negara Jepang. Sebagian besar waktu dan uang yang dimiliki oleh otaku anime dihabiskan hanya untuk menyaksikan film anime secara berkala. Fenomena otaku anime merambah berbagai kelompok masyarakat, dewasa dan juga remaja. Penelitian ini berusaha untuk menggambarkan bagaimana otaku anime membangun identitasnya dalam masyarakat dengan kebudayaan yang establish di atas nilai dan norma agama seperti halnya kebiasaan di Indonesia.Tujuan dalam penulisan ini adalah untuk menguraikan bagaimana mind dan self otaku anime terbentuk serta untuk memahami bagaimana society memaknai otaku anime. Penelitian ini menerapkan teori interaksi simbolik George Herbert Mead dengan pendekatan kualitatif deskriptif untuk memperlihatkan bagaimana otaku terbentuk melalui pengalaman pertama masa kanak-kanak, dan interaksi pertama dengan orang terdekat sebagai ingatan yang melekat pada diri subjek. Hasil penelitian menunjukkan bahwa pengalaman diri tersebut mendorong subjek untuk mencari komunitas yang akan membantunya untuk mengidentifikasi dirinya di tengah masyarakat yang establish, untuk menjamin kebebasannya dalam berimajinasi dan berinteraksi dengan tokoh anime favoritnya. Istilah otaku telah menjadi teks yang dikonsumsi secara bebas dan memberi makna baru bagi penggunanya untuk menemukan identitasnya dalam dunia sosial.
\end{abstract}

Kata-kata Kunci: Interaksi simbolik, george herbert mead, konsep diri, otaku, anime

\section{COMMUNICATION EVENTS IN FORMING THE SELF CONCEPT OF OTAKU ANIME}

\begin{abstract}
Otaku anime is a term to describe a person with a specific obsession with japanesse cartoon, in this case, called "Anime". Most of their time and money were used to collected and watch anime movies all the time. This phenomena, not only in Japan but also in the world, include Indonesia, effected in may kind of people, old and young. This research simply trying to describe how otaku anime's develop their identity inside a multicultural society just like Indonesia with the differencess in habits, religion and culture by using the term mind, self and society. The purpose of this research is to describe how the mind and self of otaku anime is formed and to understand how society interpret the anime otaku. This research applies the symbolic interaction theory from George Herbert Mead, with descriptive quantitative approach to showing how childhood experience and first interaction formed the subject behavior as memory that attach inside themselves. The result aslo showing that self experience drove the subject to find community that support and give them safety feeling to develop their identity which are used to ensure their freedom to fantasy and interact with other people in otaku community. This term, "otaku", changed its meaning and used by their owner to find and establish their identity in they world.
\end{abstract}

Keywords: Symbolic interactionism, george herbert mead, self-concept, anime, otaku

Korespondensi: Uliviana Restu Handaningtias, S.Sos., M.I.Kom. Program Studi Ilmu Komunikasi Fakultas Ilmu Sosial dan Ilmu Politik. Universitas Sultan Ageng Tirtayasa.Email: ulivianarestu@gmail.comzzz 


\section{PENDAHULUAN}

Otaku secara harfiah merupakan istilah yang digunakan oleh masyarakat Jepang untuk menggambarkan remaja laki-laki maupun perempuan yang umumnya berusia antara 1529 tahun dan memiliki hobi membaca komik, mengoleksi komik serta aksesoris yang berkaitan dengan komik atau biasa disebut Anime (bahasa Jepang untuk menyebutkan istilah kartun). Otaku secara tekun dan ulet terus menggali informasi tentang anime yang mereka sukai, mengkoleksi berbagai barang (figure models, poster, film, musik latar, buku komik, boneka, dan sebagainya) yang mengikuti model dalam film anime. Kebutuhan otaku akan anime telah mencapai tahap yang ekstrem, diberitakan oleh Kompas (2008), seorang pria Jepang meminta ijin untuk menikah dengan tokoh kartun yang disukainya.

Menjadi seorang otaku ditengah budaya Indonesia yang penuh dengan interaksi langsung antar sesama manusia, tentunya menjadi satu tantangan tersendiri bagi seorang otaku. Otaku umumnya memilih untuk menyendiri dan menghabiskan waktunya untuk membaca komik, menonton film animasi atau hanya sekedar berfantasi dengan model figure yang dimilikinya. Di Indonesia, fenomena otaku dapat dilihat dari maraknya fanbase atau perkumpulan anime. Awal berdirinya perkumpulan tersebut atas dasar minat terhadap budaya Jepang, yang mendorong lahirnya forum-forum diskusi di internet yang mengakomodasi segala bentuk kebutuhan otaku mulai dari obrolan group tentang suatu anime atau idol group seperti www.iniotaku.com, hingga munculnya Japan Matsuri atau festival budaya Jepang yang dijadikan satu dengan kebudayaan Indonesia menghasilkan sebuah dilema baru.

Di satu sisi, otaku diajak untuk berinteraksi dengan berbagai lapisan masyarakat yang tidak memiliki kegemaran yang sama, tetapi memiliki akses untuk masuk kedalamnya dan berusaha untuk berinteraksi dengan para otaku, namun di satu sisi, hal ini justru akan mengokohkan eksistensi otaku anime untuk berinteraksi dengan sesamanya. Interaksi yang kemudian menjadi wadah untuk saling bertukar informasi, bertukar barang, hingga saling berbagi obsesi dan opini. Banyaknya simbol yang dipertukarkan dalam interaksi yang dilakukan oleh otaku, menjadikan interaksi tersebut sebagai peristiwa komunikasi tempat dimana tanda dikonsumsi dan diinterpretasikan ulang. Dalam interaksi tersebut, pelaku (otaku) memilih, memeriksa, menahan, menyusun kembali dan mengubah makna untuk mengetahui situasi dimana ia ditempatkan dan arah dari tindakan-tindakannya.

Peristiwa komunikasi yang dilakukan oleh otaku, sebagian besar akan membangun identitas bersama otaku. Identitas yang kemudian dapat digunakan untuk membedakan antara otaku dengan masyarakat biasa. Identitas ini, dalam interaksionis simbolik, dapat diuraikan melalui 3 konsep sederhana, yaitu; mind, self, dan society. Ketiga konsep tersebut akan memotivasi otaku dalam mengembangkan sendiri tanda dan bahasa, dan dengan demikian, bahasa serta tanda tersebut akan menciptakan realitas baru dalam dunia otaku, dan lebih jauh lagi dalam dunia sosial masyarakat Indonesia.

Konsep diri merupakan refleksi dari seorang individu mengenai dirinya sendiri yang bersifat pribadi, dinamis dan evaluatif. Secara singkat, konsep diri merupakan pandangan dimana seorang individu mampu mengetahui apa yang dimilikinya, yaitu kelebihan dan kekurangannya. George Herbert Mead menjelaskan konsep diri sebagai pandangan, penilaian, dan perasaan individu mengenai dirinya yang timbul sebagai hasil dari suatu interaksi sosial (Burns, 1993: 80). Konsep diri sendiri berkembang oleh banyak faktor. Tapi faktor pengalaman-pengalaman yang diperoleh dari interaksi dengan lingkungan merupakan faktor utama dalam membentuk konsep diri seseorang. Sedangkan identitas diri berkaitan dengan cara memahami perbedaan dirinya dengan yang lain, dalam pandangan masyarakat (Herawati, 2016).

Rakhmat menjelaskan bahwa konsep diri mempunyai pengaruh yang cukup besar terhadap perilaku individu, yaitu individu akan bertingkah laku sesuai dengan konsep diri yang dimiliki (Rakhmat, 2000: 104). Jadi bagaimana seorang individu melakukan interaksi di masa kecilnya, itu akan terus dibentuk hingga dia memiliki pandangan tentang dirinya sendiri. Dari proses pembentukan konsep diri tersebut akan membentuk suatu karakter yang: extrovert, optimis dan memiliki kepercayaan diri yang baik atau konsep diri yang positif, ataupun terbentuknya konsep diri yang introvert, pesimis dan kurang percaya diri atau 
memiliki konsep diri yang negatif. Calhoun dan Acocella menjelaskan bahwa konsep diri terdiri atas tiga dimensi, yaitu: 1). Pengetahuan terhadap diri sendiri yaitu seperti usia, jenis kelamin, kebangsaan, suku bangsa, dan lainlain, 2). Pengharapan mengenai diri sendiri yaitu pandangan tentang kemungkinan yang diinginkan terjadi pada diri seseorang di masa depan. Pengharapan ini merupakan diri ideal. 3). Penilaian tentang diri sendiri yaitu penilaian antara pengharapan mengenai diri seseorang dengan standar dirinya yang akan menghasilakan rasa harga diri yang dapat berarti seberapa besar seseorang menyukai dirinya sendiri (Calhoun \& Acocella 1990: 67).

Dimensi konsep diri mampu menembus pandangan dan penilaian seseorang terhadap dirinya sendiri. Dimensi yang ditembus dari dimensi konsep diri antara lain fisik, diri pribadi, diri keluarga, diri moral-etik, dan juga diri sosial yang diperoleh dari proses interaksi yang dialami dan terjadi pada kehidupan mereka sehari-hari.Aspek-aspek konsep diri seperti jenis kelamin, agama, kesukuan, pendidikan, pengalaman, rupa fisik kita, dan sebagainya, diinternalisasikan lewat pernyataan (umpan balik) orang lain yang menegaskan aspek-aspek tersebut kepada orang lain, yang pada gilirannya menuntut orang tersebut untuk berperilaku sesuai dengan pandangan (image) yang tercipta. Howard F. Stein dan Robert F. Hill menyebutnya inti diri (the core of one's self). Sedangkan George De Vos (dikutip dalam Rakhmat 2007: 9) menyatakannya sebagai "perasaan kontinuitas dengan masa lalu, perasaan yang dipupuk sebagai bagian penting definisi diri."

Setiap manusia yang menjalani hidupnya, pasti tidak dapat lepas dari proses komunikasi yang dilakoninya. Komunikasi yang dilakukannya, terdapat interaksi antar individu yang membutuhkan simbol-simbol sebagai alat untuk saling bertukar pesan. Simbol-simbol pesan tersebut dapat berbentuk verbal maupun nonverbal. Pesan-pesan tersebut tentunya mengandung makna yang dimengerti oleh individu-individu yang berinteraksi di dalam sebuah proses komunikasi tersebut. Adapun Interaksi antar individu akan melibatkan proses berbagi makna melalui simbol tertentu yang disebut pesan (Nurtyasrini \& Hafiar, 2016).

Mulyana (2002) menjelaskan tiga premis utama dalam teori interaksionisme simbolik: Pertama, individu merespons suatu situasi simbolik. Ketika mereka menghadapi suatu situasi, respon mereka bergantung pada bagaimana mereka mendefinisikan situasi yang dihadapi dalam interaksi sosial. Jadi, individu yang dipandang aktif dalam menentukan lingkungan sendiri. Kedua, makna adalah produk interaksi sosial, karena itu makna tidak melekat pada objek, melainkan dinegosiasikan melalui penggunaan bahasa. Individu membayangkan atau merencanakan apa yang akan mereka lakukan. Ketiga, makna yang diinterpretasikan individu dapat berubah dari waktu ke waktu, sejalan dengan perubahan situasi yang ditemukan dalam interaksi sosial. Perubahan interpretasi dimungkinkan karena individu dapat melakukan proses mental, yakni berkomunikasi dengan dirinya sendiri.

Tiga konsep utama dalam teori Mead merupakan aspek-aspek yang berbeda dari proses umum yang sama yang disebut tindak sosial. Tindakan dimulai dengan sebuah dorongan; melibatkan persepsi dan penunjukan makna, repetisi mental, pertimbangan alternatif, dan penyempurnaan (Littlejohn \& Foss, 2009: 232). Pikiran (Mind) adalah mekanisme penunjukan-diri (self-indication), untuk menunjukan makna kepada diri sendiri dan kepada orang lain. Pikiran menghasilkan suatu bahasa isyarat yang disebut simbol. Simbolsimbol yang mempunyai arti bisa berbentuk gerak gerik atau gesture tapi juga bisa dalam bentuk sebuah bahasa.

Pikiran adalah hal yang membedakan manusia dengan makhluk hidup lainnya. Pikiran mengisyaratkan kapasitas dan sejauh mana manusia sadar akan diri mereka sendiri, siapa, dan apa mereka, objek di sekitar mereka, dan makna objek tersebut bagi mereka. Sehingga makna yang dibentuk akan dibagi bersama dan akan menciptakan suatu kefahaman yang lebih luas. Ketika individu mengetahui berbagai macam simbol-simbol yang ada, maka selanjutnya individu tersebut berpikir melalui situasi yang ada. Kemudian individu tersebut mengidentifikasi, menamai, dan memaknai simbol tersebut secara konsensus. Selanjutnya individu tersebut menanamkan kedalam memorinya untuk lebih memperkaya makna simbol-simbol yang ada disekitarnya dan menempatkan ke dalam gambaran khas miliknya sendiri dalam dunianya sendiri.

Diri Sendiri (Self) didefinisikan sebagai 
sesuatu yang dirujuk dalam pembicaraan biasa melalui kata ganti orang pertama tunggal, yaitu "aku"(I), "daku" (me), "miliku" (mine)", dan "diriku" (myself) (Mulyana, 2010: 73). Seseorang memiliki dirinya karena dia dapat merespon dirinya sendiri sebagai sebuah objek. Individu kadang bereaksi dengan baik kepada dirinya melalui perasaan bangga, bahagia dan merasa dirinya pemberani, tapi tidak jarang juga individu marah, kesal, dan jijik pada dirinya sendiri.

Self atau diri merujuk kepada kapasitas dan pengalaman yang memungkinkan manusia menjadi objek bagi diri mereka sendiri. Kemunculannya bergantung kepada kemampuan individu untuk mengambil peran orang lain dalam lingkunga sosialnya. Melalui proses pengambilan peran ini, individu menginternalisasikan norma-norma kelompoknya, mulai dari keluarganya, kelompok sebaya, kelompok masyarakat hingga bangsanya. Individu bergaul dengan orangorang lain ini berdasarkan norma-norma tersebut yang memungkinkan individu tersosialisasikan (Mulyana, 2010: 87). Cara pandang orang lain inilah yang menyebabkan individu memiliki konsep diri. Proses melihat diri sendiri melalui sudut pandang orang lain merupakan cara yang efektif bagi seorang individu masuk kedalam tatanan sosial. karena individu tersebut mampu untuk menilai kekurangan ataupun kelebihan yang ada pada dirinya sendiri.

Perkembangan diri secara jelas dapat diamati pada anak-anak. Menurut Mead, perkembangan diri terdiri dari dua tahap umum yang ia sebut tahap permainan (play stage) dan tahap pertandingan (game stage). Tahap permainan adalah perkembanganpengambilan peran bersifat elementer yang memungkinkan anak-anak melihat diri mereka sendiri dari perspektif orang lain yang dianggap penting. Tahap selanjutnya, tahap pertandingan berasal dari proses pengambilan peran dan sikap orang lain secara umum. Pada tahapan ini anak mulai memasuki komunitasnya (Mulyana, 2010: 87).

Schutz (dalam Mulyana, 2010: 88-87) menganggap self atau diri ini yang melakukan tindakan masa lalu (modo praeterito) sebagai suatu diri yang parsial dan sebagai pengambilan suatu peran. Tindakan dianggap sebagai hasil dari tahap-tahap yang dialektis ini. Diri yang lengkap, atau diri dengan ekspresi yang penuh, menurut Mead, tidak hanya merupakan daku, yang mengorganisasikan dan mengambil sikap orang lain kedalam dirinya, namun sekaligus merupakan daku dan aku.

Masyarakat (Society) dipahami sebagai proses berkehidupan ditengah kelompok yang terdiri atas perilaku-perilaku anggotanya, manusia diharuskan untuk memahami maksud orang lain yang juga mengharuskan kita untuk mengetahui apa yang akan kita lakukan selanjutnya. Artinya, didalam kelompok itu individu diharuskan untuk dapatmembaca tindakan dan maksud orang lain serta menanggapinyadengan cara yang tepat. Cooley beranggapan bahwa poin diri dan masyarakat yang dikembangkan oleh Mead ini sangatlah berkaitan dan memiliki efek yang besar. Cooley memberi ilustrasi bahwa perasaan diri dan masyarakat ini dikembangkan lewat penafsiran individu atas realitas fisik dan sosial, termasuk aspek-aspek pendapat mengenai tubuh, tujuan, materi, ambisi, dan gagasan apapun atau sistem gagasan yang berasal dari kehidupan komunikatif yang dianggap sebagai milik individu.

Cooley juga menegaskan bahwa perasaan diri bersifat sosial, karena maknanya dicipakan melalui bahasa dan budaya bersama dan karena hal itu berasal dari interpretasi subjektif individu atas penilaian orang-orang lain yang mereka anggap pentingdan punya hubungan dekat dengan mereka (significant others) mengenai sikap dan tindakan individu tersenut. Jadi diri dan masyarakat saling mempengaruhi, masingmasing berfungsi sebagai rujukan bagi yang lainnya, sehingga kedua disebut kembar (twin born). (dalam Mulyana, 2010: 74).

Masyarakat terdiri atas sebuah jaringan interaksi sosial dimana anggota-anggotanya menempatkan makna bagi tindakan mereka dan tindakan orang lain dengan menggunakan simbol-simbol yang digunakan ditengah masyarakat tersebut. Mereka membangun simbol agar dapat dipahami anggotanya. Simbol tersebut biasanya hanya dipahami oleh komponen masyarakat yang tergabung di dalamnya. Society atau masyarakat merupakan kumpulan dari berbagai macam aspek sosial yang ada di dalam kehidupan masyarakat. Antara lain adat, suku bangsa, budaya, hingga kepada aspek agama. Sehingga perkembangan interaksi yang dilakukan oleh significant others dan refence groups akan sangat vital untuk mempengaruhi pembentukan konsep diri seseorang individu 
untuk siap terjun kedalam tatanan masyarakat. Perkembangan masyarakat bejalan dinamis seiring dengan berjalannya perkembangan mind atau pikiran manusia. Sehingga antara pikiran dan masyarakat merupakan sebuah bagian yang sudah terintergralkan dan tidak dapat dipisahkan.

Otaku dipahami sebagai seseorang yang memiliki ketertarikan yang berlebih pada animasi kartun Jepang. Istilah lain yang umum digunakan untuk menyebut otaku adalah dengan istilah Japan Freak. Hal ini dikarenakan gaya hidup mereka yang dipenuhi dan tidak bisa lepas dengan berbagai hal yang berhubungan dengan Jepang ataupun budaya populernyanya seperti anime dan manga. Tentunya masih banyak istilah yang digunakan dalam menyebut otaku seperti Japan Mania ataupun Japan Holic di tempat lainnya. otaku dapat didefinisikan sebagai gambaran mengenai seseorang yang memiliki kecintaan terhadap sesuatu hal dengan tingkat fanatisme yang tinggi. Hal ini diperkuat oleh gagasan Galbraith (2010) dalam jurnalnya ia mendefinisikan otaku sebagai hardcore fans (penggemar fanatik) terhadap anime, manga, dan game yang mengidolakan (memuja) karakter fantasi.

Sedangkan dalam jurnal yang ditulis oleh Ken Kitabayashi dan di release oleh Nomura Research Institute memfokuskan pengertian otaku sebagai konsumen yang banyak menghabiskan waktu dan uang untuk hobi yang dimilikinya dan mereka memiliki ciri-ciri psikologis yang unik (Kitabayashi, 2004). Sejak tahun 2008 kamus Oxford mulai memasukan istilah otaku sebagai "a young person who is obsessed with computer or particular aspect of popular culture to the detriment of their social skills." Dengan terjemahan "Orang muda yang memiliki obsesi dengan perangkat komputer atau aspek-aspek dari budaya popular hingga merusak kemampuan bersosialisasi mereka". Menurut definisi tersebut, dapat disarikan bahwasanya otaku memiliki ketertarikan yang luar biasa terhadap sesuatu hal, baik itu yang terhadap sesuatu yang memiliki bentuk atau juga yang bersifat imajiner dan otaku anime menghabiskan banyak sumber daya yang mereka miliki seperti uang dan waktu untuk memenuhi hasrat mereka.

Ciri-ciri yang dapat dilihat dari seorang otaku diantaranya adalah mereka selalu berbagi gambar anime ataupun manga di media sosial yang mereka miliki, mengkoleksi action figure dari tokoh-tokoh anime atau manga favoritnya, berusaha hadir dalam setiap event budaya Jepang, mengikuti cosplay, dan memiliki koleksi merchandise anime dan manga yang relatif banyak. Saitou (2007: 227) mendeskipsikan karakteristik otaku sebagai berikut: Memiliki ketertarikan terhadap konteks fiksional, Memaksa untuk memfiksionalisasikan objek untuk dapat merasakan cinta, Memiliki beragam orientasi untuk menikmati objek-objek fiksi, Bagi otaku, objek fiksional dapat menjadi objek seksual.

Otaku memiliki kecenderungan untuk menarik diri dari dunia luar dan memilih mengurung dari kehidupan sosial dan selanjutnya mereka akanterus berdiam diri didalam rumah. Di Jepang, otaku dalam tingkatan semacam ini disebut dengan hikimori. Seorang otaku yang kecanduan berat dapat memiliki kelainan seksual, dengan menyukai karakter kartun 2 dimensi dari pada manusia normal pada umumnya. Lee Jin-gyu (28 tahun), pria asal Korea Selatan jatuh cinta dengan "dakimakura", dan telah resmi menikah dengan dakimakura-nya. Otaku jenis ini disebut dengan nijikon. Jurnal elektronik yang direlease oleh Nomura Research Institute, sebuah perusahaan besar di Jepang yang bergerak di bidang konsultasi informasi teknologi yang telah berdiri sejak tahun 1965 mengklasifikasikan otaku kedalam 12 bidang, yaitu: Anime, Manga, Idols, games, komputer, peralatan audio-visual, peranti telekomunikasi, otomotif dan robotik, travel, Fashion, Kamera, dan perkeretaapian, Nomura Research Institute menyatakan hal ini sebagai; "New Market scale Estimation for otaku”.

\section{METODE PENELITIAN}

Penelitian ini menggunakan pendekatan kualitatif deskriptif dengan karakteristik; dilakukan pada kondisi yang alamiah, langsung ke sumber data dan penulis adalah instrument kunci; bersifat deskriptif, data yang terkumpul berbentuk kata-kata dan gambar, sehingga tidak menentukan pada angka. Penelitian kualitatif lebih menekankan pada proses dari pada produk atau outcome dengan melakukan analisis data secara induktif dan menekankan pada makna (data dibalik yang teramati). Dengan demikian, data yang akan didapatkan oleh Penulis tidak 
bersifat mencari kebenaran, tetapi lebih kepada pemahaman subyek terhadap dunia sekitarnya. Tetapi tetap menggunakan data utama yang cermat dalam mencari jawaban akan pokok permasalahan.

\section{HASIL DAN PEMBAHASAN}

Otaku berawal dari hobi menonton anime yang berlangsung sejak kecil. Hobi ini memberi kepuasan tertentu yang tidak sama dengan menonton film selain anime. kebiasaan menonton yang dilestarikan sejak kecil menuntun perilaku otaku menjadi penggemar yang lebih intens, mulai dari koleksi action figure ataupun aksesoris lain yang berhubungan dengan anime tersebut. Tidak semua otaku akan menyukai genre film yang sama. Ketertarikan genre umumnya bersifat psikologis, berkaitan dengan apa yang dialami subjek dalam kebiasaan masa kecilnya. Perhatikan pernyataan informan 3 berikut: "Gue sih lebih suka genre yang petualangan semacem One Piece sama Gintama. Seru aja ngikutin perkembangannya tiap minggu. Jadi ada yang ditunggu-tunggu gitu dan jadinya bikin penasaran”.

Tontonan film animasi sejak mereka kecil, kondisi kehidupan keluarga dan ada atau tidaknya saudara yang dimiliki akan membawa mereka pada satu kondisi dimana mereka akan memiliki kecenderungan untuk memilih genreanime yang mereka sukai ketika dewasa. Seperti yang dinyatakan oleh informan kedua yang menyukai film bergenrepertualangan dan action pada saat kecil. Ketika menginjak dewasa, ia lebih menyukai film anime yang bergenre action-fantasy. "Gue sih lebih suka genre yang petualangan semacem One Piece sama Gintama. Seru aja ngikutin perkembangannya tiap minggu. Jadi ada yang ditunggu-tunggu gitu dan jadinya bikin penasaran”.

Penegasan berulang yang dinyatakan oleh informan, juga memberi ciri bahwa otaku lahir dari pengalaman pertama, situasi yang paling awal yang diingat oleh subjek dan pengaruh dari interaksi yang dilakukan subjek dengan orang-orang terdekatnya saat itu; seperti halnya kakak atau adik. Kebebasan imajinasi dan interpretasi terhadap cerita anime, memberi daya tarik tersendiri bagi subjek sehingga menjadi otaku. Kebebasan imajinasi tersebut tidak hanya terjadi pada saat subjek membaca cerita anime dalam bentuk tertulis, atau menonton film anime, tetapi juga terjadi pada saat subjek mengkoleksi action figure, poster, kostum, dan berinteraksi dengan otaku lainnya. Kebebasan imajinasi juga menjamin subjek untuk berinteraksi dengan tokoh anime yang disukainya, bagi beberapa orang aktivitas interaksi imajiner tersebut seringkali tidak dipahami dan dianggap sebagai aktivitas tidak normal. Anggapan tersebut mendorong otaku untuk menjauh dari masyarakat dan berusaha untuk menjaga privasi dirinya sehingga tidak dianggap sebagai sesuatu yang salah secara sosial. Subjek yang terintimidasi secara sosial akan melabeli dirinya dengan berbagai sebutan dan istilah baru selain kata otaku .

Informan menjadi otaku bukan karena dorongan orang lain, tetapi karena secara konseptual, informan merasa bahwa dirinya diterima dengan baik dan kebutuhannya terpenuhi. Otaku umumnya akan bergabung dalam satu komunitas yang sama, di dalam komunitas tersebut, setiap anggota bebas berinteraksi dan berekspresi tanpa ada penghakimanolehanggotalain.Otakujugabukan upaya untuk meniru orang lain, bahkan dalam penelitian terlihat bahwa setiap otaku memiliki karakternya masing-masing dan bertahan dalam imajinasi ciptaannya sendiri. Privasi ini juga terlihat dari beberapa kasus otaku di dunia, di antaranya kasus pria asal China yang menikah dengan tokoh kartun idolanya. Karakter otaku dibangun berdasarkan kesukaannya terhadap tokoh animasi tersebut, semakin obsesif otaku terhadap sang tokoh, semakin permisif sikapnya terhadap masyarakat secara umum. otaku akan berusaha menghindari pertemuan-pertemuan publik yang akan menghalangi kebebasannya dalam berinteraksi dengan sang tokoh idola. Pada tahap ini, informan telah menjadi otaku kelas berat.

Salah satu informan menunjukkan tanda bahwa kesenangannya pada anime adalah upayanya untuk memberi identitas baru pada dirinya yang dianggap kurang percaya diri. Hal ini berkaitan dengan kebebasan berekspresi tersebut, bahwa otaku melihat dirinya kedalam tokoh animasi tersebut, berusaha untuk membangun sifat baru untuk menutupi sifat yang dimilikinya saat ini. Informan umumnya tertarik dengan tokoh yang memiliki ciri khas atau latar belakang yang (dianggapnya) sama dengan dirinya, misalnya tokoh animasi tersebut tidak pandai, sembrono, berantakan, 
tapi memiliki keberanian, setia kawan, dan disukai oleh semua orang, maka informan akan berusaha mengidetikkan dirinya sedekat mungkin dengan tokoh tersebut. Upaya tersebut menjadikan tokoh animasi sebagai diri di dunia yang lain.

Istilah otaku lahir dari keinginan informan untuk memberi identitas pada dirinya dan cara hidupnya. Di dorong oleh ketidaktahuan masyarakat akan perilaku yang tidak dipahaminya, otaku berusaha membangun dunia "aman" bagi dirinya dan juga sesama otaku lainnya. Masyarakat secara umum sulit menerima perubahan, terutama jika perubahan tersebut merusak tatanan sosial yang telah berlangsung ratusan tahun. Sebagian besar masyarakat akan memilih untuk berada dalam dunia yang selama ini diketahui dan dikenalnya, dan akan berusaha memastikan semua orang yang terlibat didalamnya untuk tidak melewati batas pengetahuan tersebut. Akan tetapi, seperti halnya peristiwa komunikasi lainnya, maka interaksi antar manusia selalu menghasilkan sikap baru, perilaku baru, dan opini baru, disertai dengan kebiasaan baru dan budaya baru. Hal ini terjadi pada subjek yang menyukai segala hal tentang anime. Pandangan tidak wajar yang diterima subjek oleh masyarakat tidak menghilangkan hasrat tersebut, sebaliknya justru mendorong informan untuk memberi identitas baru pada dirinya, yaitu; otaku .

Ketika istilah otaku digunakan oleh informan dan anggota komunitas, istilah tersebut menjadi bahasa baru dalam dunia komunitas tersebut. Dalam siklus tanda, istilah otaku telah menjadi teks yang dikonsumsi oleh masyarakat dan memberi makna baru bagi perilaku subjek dan anggota komunitas. Secara sederhana, otaku yang ada di Indonesia, memiliki perbedaan karakter dengan otaku yang berasal dari Jepang ataupun negara lain. Otaku anime di Indonesia secara sadar akan membatasi perilakunya ketika berada pada lingkungan sosial yang asing dan berusaha untuk tidak menonjolkan diri, sehingga tidak menimbulkan impresi negatif dari masyarakat di sekitarnya. Bagi masyarakat, otaku anime tidak terlihat janggal ataupun aneh. Berbeda dengan otaku di Jepang yang secara fisik dan penampilan terlihat mencolok diantara masyarakat umum, akan tetapi karena masyarakat Jepang telah memahami otaku dan menerima sebagian besar komunitas tersebut, maka impresi masyarakat pun wajar dan tidak mengucilkan. Hal ini juga menjadi poin pembeda dengan masyarakat di Indonesia. Apabila ada otaku yang sehari-hari berdandan serba hitam, meniru tokoh kartun tertentu, maka pandangan masyarakat terhadap oran tersebut cenderung negatif.

Otaku adalah fenomea yang lahir untuk memenuhi kebutuhan individu akan pengakuan diri. Masyarakat yang semakin haus akan hiburan, yang termanjakan oleh berbagai akses komunikasi tanpa batas, memasuki ruang-ruang yang sebelumnya tabu menjadi kewajaran bahkan kebutuhan. Jika 20 tahun sebelumnya, memajang kemesraan antara suami dan istri adalah aib, maka saat ini semua orang berlomba memotret kehidupan pribadinya dan membagikannya ke seluruh dunia melalui facebook, twitter, instagram, dan sebagainya. Jika sebelumnya, menghujat orang lain adalah tindakan yang tercela, maka saat ini sudah dikenal adalanya cyber bullying. Jika sebelumnya prostitusi hanya terjadi di dalam gang-gang sempit dan gelap, maka saat ini, prostitusi mewabah dalam berbagai e-commerce dan online shop (bayangkan! Hanya dengan meng-klik tombol anda sudah bisa "memesan" dan membeli seorang wanita). Otaku lahir diantaranya. Menjadi salah satu fenomena sosial dengan legitimasi dari orang-orang yang membutuhkan pengakuan diri dan pemuasan akan hiburan. Ketika dunia tidak lagi seindah dunia peri ataupun semenarik tokoh hero.

\section{SIMPULAN}

Konsep diri otaku berasal dari proses yang terjadi semenjak masa kanak-kanak, dimulai dari pengalaman pertama, ingatan pertama, dan interaksi pertama dengan orang-orang terdekat, seperti halnya keluarga inti. otaku Indonesia menitikberatkan pada upaya subjek agar diterima oleh masyarakat secara umum dan tidak dipandang sebagai perilaku di luar norma dan budaya. Upaya tersebut dapat dilihat dari identitas yang dibangun dalam berbagai kegiatan; festival budaya Jepang, festival kostum (cosplay), klub membaca komik, fanpage, dan sebagainya. Istilah otaku telah menjadi wacana yang memberi identitas bagi subjek untuk meneruskan perannya dalam interaksi sosial dengan masyarakat umum, identitas yang kemudian akan memberi kebebasan bagi subjek untuk beraktivitas dan berekspresi 
secara terbuka. (1) Penelitian ini hanya sebatas memberi gambaran bagaimana otaku membangun identitasnya dalam kehidupan sosial masyarakat di Indonesia. Penelitian lanjutan disarankan untuk menguraikan mengenai berbagai fenomena sosial yang lahir di era milenium, serta menggambarkan bagaimana dampaknya terhadap masyarakat. Fenomena seperti otaku anime, merupakan pengejewantahan dari kebutuhan manusia akan hiburan dan pengakuan diri. Akan jauh lebih menarik apabila penelitian ini dilanjutkan dengan menggunakan konstruktivis ataupun analisis wacana kritis. (2) Masyarakat Indonesia tumbuh dan berkembang secara multikultural, maka sewajarnya jika masyarakat juga turut menyadari fenomena yang tengah berkembang, berusaha memahami fenomena tersebut tidak hanya sisi negatifnya saja tetapi juga sisi lainnya. Dengan demikian, masyarakat turut andil dalam berkembangnya peradaban yang lebih humanis.

\section{DAFTAR PUSTAKA}

Agustianti, H. (2006). Psikologi perkembangan: pendekatan ekologi kaitannya dengan konsep diri dan penyesuaian diri pada remaja. Bandung: Refika Aditama

Burns, R. B. (1993). Konsep diri teori, pengukuran, perkembangan, dan perilaku. Jakarta: Arcan

Calhoun \& Acocella. (1990). Psikologi tentang penyesuaian dan hubungan kemanusiaan. Semarang: Penerbit IKIP Semarang

Effendy, O. U. (2007). Ilmu, teori, dan filsafat. Bandung: Citra Aditya Bakti

Effendy, O. U. (2007). Ilmu komunikasi teori dan praktek. Bandung: Remaja Rosdakarya

Galbraith, P. W. (2009), MOE: Exploring virtual potential in post-millenia japan, electronic jourrnal of contemporary japanese studies 5. Diakses dari http://www.japanesestudies.org.uk/ articles/2009/Galbraith.html pada tanggal 27 April 2014 pukul 01.19

Herawati, M. (2016). Pemaknaan gender perempuan pekerja media di jawa barat. Jurnal Kajian Komunikasi, 4/1, 84-94

JepangNet. (2010). Orang korea menikah dengan guling. Diakses dari http:// www.jepang.net/2010/03/orang-koreamenikah-dengan-guling.htmlpada tanggal 26 april 2014 pukul 22.56

Kitabayashi, K (2004). The otaku group from a buisness perspective: revaluation of enthusiastic customers, nomura research institute, Diakses dari http://www. nri.com/global/opinion/papers/2004/ np200484.html pada tanggal 27 April 2014 pukul 00.38

Kompas. (2008). Pria jepang izin menikahi tokoh komik. Diakses dari http://nasional. kompas.com/read/2008/10/31/13230553/ pria.jepang.izin.menikahi.tokoh.komik

Kountur, Rony. (2007). Metode Penelitian. Jakarta: PPM

Littlejohn, S. W. \& Karen, A, F. (2009). Teori komunikasi: theories of human communication. Jakarta: Salemba Humanika

Mulyana, D. (2002), Multiplisitas identitas etnik: orang Indonesia di Melbourne dalam Jurnal elektronik, Diakses dari https://ikomunand.files.wordpress. com/2011/01/telaah-hasil-penelitankel-11.pptx $+\& \mathrm{~cd}=1 \& \mathrm{hl}=$ en $\& \mathrm{ct}=\mathrm{clnk} \& \mathrm{c}$ lient=firefox-a,diunduh pada tanggal 15 Desember 2014 pukul 00.32

Mulyana, D. (2005). Ilmu komunikasi suatu pengantar. Bandung: Remaja Rosdakarya

Mulyana, D. (2010). Metode penelitian kualitatif. Bandung: Remaja Rosdakarya

Moleong, L. J. (2001). Metode penelitian kualitatif. Bandung: Remaja Rosdakarya

Nomura Research Institute. "New Market scale Estimation for otaku”, Nomura Resarch Institute, Diakses dari http://www.nri. co.jp/english/news/2005/051006.html pada tanggal 5 mei 2014 pukul 23.38

Nurtyasrini, S. \& Hafiar, H. (2016). Pengalaman komunikasi pemulung tentang pemeliharaan kesehatan diri dan lingkungan di tpa bantar gebang. Jurnal Kajian Komunikasi, 4/2(8), 219-228

Rakhmat, J. (2000). Psikologi komunikasi. Bandung: Remaja Rosdakarya

Rakhmat, J. (2007). Psikologi komunikasi. Bandung: Remaja Rosdakarya

Ruslan, R. (2003). Metode penelitian public relations dan komunikasi. Jakarta: Raja Grafindo Persada

Sugiyono. (2008). Metode penelitian kuantitatif kualitatif dan R\&D. Bandung: Alfabeta

Widjaja. (2002). Komunikasi dan hubungan masyarakat. Jakarta: Bumi Aksara 